\title{
LUIS ASTEY
}

Margit Frenk*

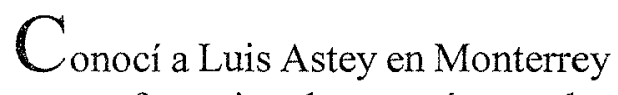

por los años 60, cuando fui a dar una conferencia sobre poesía popular sefardi. Había oído hablar mucho de él; era, me decía mi amiga Gloria Ruiz de Bravo Ahuja, un hombre que sabía muchísimo y que tenía una erudición fuera de todo lo imaginable; recuerdo que me lo pintó como una especie de asceta humanista, que vivía retraído; al menos, ésa es la imagen que me formé de él antes de viajar a Monterrey aquella vez. Aquella vez, pues, lo conocí, y recuerdo que tuvimos una buena conversación; fue el comienzo de lo que sería luego una larga amistad.

Cuando Astey se vino a vivir a México nos vimos con cierta frecuencia. Alma Wood, a punto de ser su esposa, estudiaba el Doctorado en El Colegio de México y fue mi alumna; ella y yo compartíamos, entre otras cosas, el interés y el gusto por las jarchas mozárabes, sobre las que Alma, dirigida por Astey, había hecho su tesis de Licenciatura en el Tecnológico de Monterrey y yo, escrito y publicado mi tesis doctoral en El Colegio. Luis Astey, por cierto, fue sinodal en mi examen, en 1972, y en esa ocasión -lo tengo muy presente, y también él lo recordaba- le fallé, le tuve que fallar. En mi tesis yo abordaba las teorías sobre los supuestos orígenes populares de la lírica europea, basando parte de mi exposición en un excelente libro berlinés, de Paul Levy (1911), que recoge todas las ideas de los románticos alemanes sobre el concepto de poesía popular; citaba yo, pues, de segunda mano a Herder, Goethe, Uhland, los Schlegel, los Grimm y muchísimos

* Facultad de Filosofía y Letras, UNAM. 
MARGIT FRENK

otros. En el examen, Astey me pidió que, para la publicación del libro, citara yo de primera mano a esos autores. Pero desde México, era imposible hacerlo; hubiera tenido que pasarme varios meses en bibliotecas alemanas, y yo tenía mi familia, mi trabajo y ningún dinero; así que mi libro salió tal como estaba.

He querido contar esta pequeña anécdota porque tiene mucho que ver con cómo era Luis Astey el investigador. Cuando leemos, por ejemplo su obra magna, Dramas litúrgicos del Occidente medieval, vemos la enorme cantidad de antiquísimos manuscritos e impresos rarísimos que ha manejado de manera directa, que ha leído con sus propios ojos, y nos preguntamos irremediablemente: “¿cómo pudo hacerlo?" ¿Cómo, viviendo en nuestro pobre México, se puede armar un aparato erudito de tal magnitud, si sólo los que viven en aquellas lejanas Europas -o si acaso, junto a una gran biblioteca estadounidense- tienen el privilegio de poder consultar directamente los manuscritos medievales, los incunables, los estudios y ediciones modernos de difícil acceso? Es una hazaña notable, que sólo puede explicarse por una tremenda vocación y una gran tenacidad, a prueba de todas las dificultades imaginables.

142 Pero volviendo a mi experiencia personal, quiero decir que fui también alumna de Luis Astey y pude comprobar la verdad de lo que me decían, siempre llenos de admiración, sus estudiantes: era un gran maestro. A varios compañeros del Colegio de México nos dio Astey un admirable curso sobre las civilizaciones de la Antigüedad. De eso hace ya mucho tiempo, pero recuerdo que me impresionó que un hombre tan retraído y erudito pudiera ser a la vez un verdadero Maestro, al que le importaban mucho los estudiantes.

La comunicación con Luis siguió viva, aunque espaciada, durante los tiempos que siguieron. Él me permitió preparar el primer tomo de la Biblioteca novohispana que planeó y dirigía en el Colegio; preparé entonces una edición y estudio de la poesía lírica de Fernán González de Eslava. Finalmente, hace unos años, Astey entró a la Academia Mexicana de la Lengua. Ahí nos veíamos regularmente, cada quince días: primero, en la salita de entrada, adonde él llegaba siempre con 
un paquetito de libros que acababa de comprar en una de las librerías del rumbo y que solía enseñarme; después, sentados frente a frente ante la enorme mesa llena de diccionarios en que se celebran las sesiones; después, a la salida -y ésta era la cereza del pastel-, cuando, de camino a casa, yo lo llevaba en el coche hasta la Calzada de Tlalpan, ya cerca de Acoxpa, donde él luego tomaba un taxi. El tráfico intenso de esa hora nos daba la posibilidad de platicar largamente sobre toda clase de asuntos; es verdad que muchas veces yo hablaba más que él, pero entonces él escuchaba con atención, hacía algún comentario, preguntaba. En ésas estábamos cuando yo, súbitamente, ya no pude manejar de noche y cuando, al poco tiempo, él cayó enfermo. Nunca lo pudimos hablar, y siento que nuestra amistad quedó como en suspenso. Todo se agolpó luego en aquellos últimos meses del año, y de pronto Luis Astey, el maestro, el colega, el amigo, ya no está, y nos deja con una tristeza que no se quita, y no se quitará por más que pase el tiempo.

Pero también nos deja con tantas cosas buenas. Por un lado, el recuerdo muy vivo de ese hombre de negro tan dulce, tan querible, con su largo cabello blanquísimo, su sonrisa, su lento, cauteloso hablar. Por otro, su obra, que nos sobrevivirá a todos. Leyendo los trabajos de Luis Astey, uno siente que pocas veces como en su caso el estilo de una escritura se corresponde a tal grado con el modo de ser y de hablar del escritor: la mesura, la ecuanimidad, el saber mantener bajo control las reacciones que tenía ante las cosas, aun ante aquellas que lo alteraban.

La escritura de Luis Astey, de textura densa, compacta, refleja por sí misma la complejidad de los asuntos tratados y la frecuente imposibilidad de llegar a conclusiones tajantes. Con infinita cautela, con pies de plomo, Astey se mueve por entre los laberintos de los hechos observados y de las interpretaciones. Dice, por ejemplo, sobre los personajes en los dramas de Hrotsvitha de Gandersheim, que "a través de las diversas maneras de nombrarse o de ser nombrados, de ser descritos o de describirse en cuanto figuras, y en cuanto conciencias, de revelarse a sí mismos en lo que saben que son o creen saber o fingen 
MARGIT FRENK

que son, o de ser, a partir de indicios diversamente perceptibles..." (p. 31). Astey rodea su objeto por todas partes, agotando la exploración de todos sus aspectos, penetrando en todos los resquicios,

Es a veces tal la plétora de lo que observa y de lo que quiere decir Astey, que el texto se desborda hacia las notas al pie, de lectura tan necesaria como el texto mismo. Hay que ver la extensa nota en que detalla lo que significaba en tiempo de Hrotsvitha el hecho de ser "canonesa" en un monasterio, cómo "tendrían derecho, principalmente, (a) a conservar sus bienes materiales o cederlos al monasterio (así en las reglas: monasterium), o reservarse sólo el usufructo de ellos y, en cualquiera de los tres casos, a quedar exentas, por medio de diversos procedimientos jurídicos, de toda preocupación económica; (b) a tener habitación personal (mansiuncula) en el recinto del monasterio y a contar con sirvientas propias, si bien precaviéndose de que éstas no se les convirtieran en peligro cotidiano por razón de las noticias que sobre asuntos del mundo era inevitable que les comunicasen; (c) a ser visitadas por hombres, clérigos o laicos, y comer y beber con ellos, pero frente a testigos y en el locutorio..." (p. 21-22, nota 33). Es, pues, una nota lo que nos revela la vida cotidiana de la protagonista, demasiado

144 valiosa para ser pasada por alto, pero no suficientemente importante para ocupar una porción del texto, tan medido y tan sobrio, de Astey. Es el extremo opuesto al exceso verbal al que solemos ser tan propensos.

Un ser único, pues, Luis Astey. De esos seres excepcionales que, cuando desaparecen, siguen viviendo en nuestro interior mientras vivimos nosotros, nosotras, tal como eran, sin cambiar, sin palidecer. 